\title{
Staff provision of organization as an index of its energy performance
}

\author{
Natalya Nagibina $^{1, *}$, Elena Kandybina ${ }^{1}$, Lyudmila Komyshova ${ }^{1}$, and Sergey Fedyunin ${ }^{1}$ \\ ${ }^{1}$ Voronezh State Technical University, Moscovskiy prospect, 14, Voronezh, 394026, Russia
}

\begin{abstract}
This article discusses the effective output of an organization, based on it's effective use of qualified staff. The effective management of staff and an organization is imperative for any company in the current climate. The goal is to determine the staff resources required for a specific organization and for specific tasks within that organization. These determinations are made by assessing the complexity of tasks required to be completed and the qualifications of the bank staff who complete these tasks. The complexity of each task is assessed by determining the output of work by staff members who perform these tasks and gathering analytical and statistical data. The data on the complexity of work compared to the output/performance of staff within the organization was presented by researchers and found that only $1 / 3$ of staff are performing and executing their duties to the standard required by the organization within the timeframe for the task. Workers who were not meeting their targets were working harder to achieve their goal, and the effort or time taken to achieve this, meaning the coefficient of the whole company rose from 10$50 \%$. In some categories of staff, a rise of $10-15 \%$ of standard output is considered acceptable, whereas for other groups of staff, a rise of this amount indicates extra staff are required.
\end{abstract}

\section{Introduction}

State, consumers and society in general are consistently expecting organizations to be to be proactive in the effective running and efficiency of that organization. Using effectiveness management techniques in organizations is an innovative solution that is used in conjunction with the modernization of existing procedures and management. This is based on the use of international experiences within other organizations and the results and achievements of implementing real team effectiveness practices, however the effectiveness of a business should not solely be based on technical solutions, but on the higher level also, such as further education and training of staff $[1,2]$.

The importance of providing the correct staff requirements is essential to any organization. This can be achieved through the monitoring of staff output and performance and the requirements of each task, via outsourced monitoring or by using the organizations own experience and knowledge [3].

The monitoring of staff performance and output and the recommendations of staff

${ }^{*}$ Corresponding author: nagibina.natalya@yandex.ru 
requirements through internal methods can be very labour intensive and time consuming, however, outsourcing of this task to consultants and specialists who can provide accurate and professional information is expensive [4].

\section{Materials and methods}

Presented work based on a systematic approach that has let to use as methods as systems analysis, abstract logical method, methods of analyze and synthesis. As the main method of obtain data and their first preprocessing using experienced statistical method [5-7].

Definition of organization requirements in staff realized by labour intensity of performed work by employee based on formula 1 .

$$
\mathrm{ANE}=\frac{\mathrm{SLI}}{\mathrm{EWT} \times \mathrm{IRS}}
$$

where SLI - planned standards of labour intensity;

EWT - effective worktime per one employee;

IRS - planned implementation rate of standards;

ANE - planned average number of employees.

The working time fund of one employee of the considered organization is presented in table1.

Table 1. The Fund of working time of one employee of JSC «Rosselkhozbank».

\begin{tabular}{|c|c|}
\hline \multirow{4}{*}{$\begin{array}{c}\text { Month, quarter, half year, } 9 \text { months, a } \\
\text { year }\end{array}$} & working days \\
\hline & 36 hours working week \\
\hline & five days per week \\
\hline & Days \\
\hline January & 17 \\
\hline February & 19 \\
\hline March & 20 \\
\hline 1 quarter & 56 \\
\hline April & 21 \\
\hline May & 20 \\
\hline June & 20 \\
\hline 2 quarter & 61 \\
\hline 1 half year & 117 \\
\hline July & 22 \\
\hline August & 23 \\
\hline September & 20 \\
\hline 3 quarter & 65 \\
\hline 9 months & 182 \\
\hline October & 23 \\
\hline November & 21 \\
\hline December & 21 \\
\hline 4 quarter & 65 \\
\hline Year & 247 \\
\hline Average monthly balance & 20.5 \\
\hline
\end{tabular}

So one employee working time of the considered organization should be $1772,4 \mathrm{~h}$ in a year or $147,7 \mathrm{~h}$ in a month on average.

Plan normative complexity was detected by experienced statistical method based on estimate of labour input for execution of certain types of labour by workers who make this type of work.

So using combination of methods let to make sound conclusions. 


\section{Results}

Determination of needs in staff was carried out for additional office JSC «Rosselkhozbank» - organization that has specific in providing banking services for individuals and legal entities, mainly agricultural organizations. An additional office is located in the Khlevnoye village, Lipetsk Region, is represented by six employees, and its organizational structure is shown in Fig. 1.

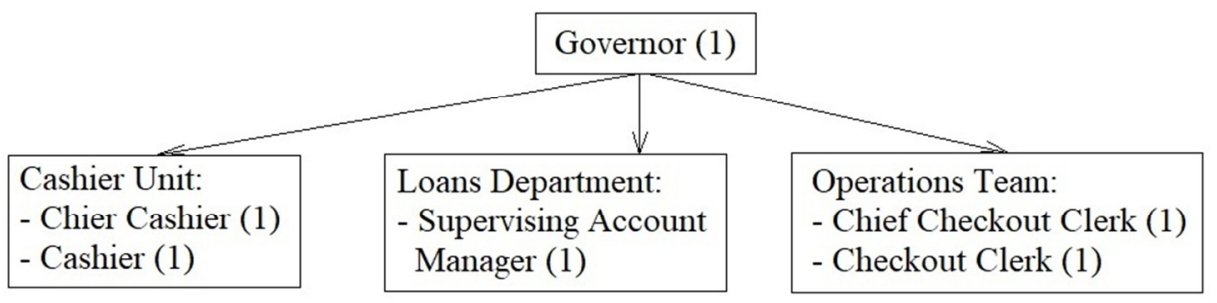

Fig. 1. The organizational structure of JSC «Rosselkhozbank».

The Determination of the planned volume of work of the cashier and the senior cashier of JSC «Rosselkhozbank» is presented in table 2.

Table 2. The Determination of the planned volume of work of the cashier and the senior cashier of JSC «Rosselkhozbank».

\begin{tabular}{|c|c|c|c|c|}
\hline № & Performed tasks/operations & $\begin{array}{c}\text { The rate of } \\
\text { time for the } \\
\text { evaluation of } \\
\text { the employee. } \\
\text { min }\end{array}$ & $\begin{array}{c}\text { Number } \\
\text { of works/ } \\
\text { operations } \\
\text { per } \\
\text { month }\end{array}$ & $\begin{array}{c}\text { Momthly } \\
\text { labour } \\
\text { input. } h\end{array}$ \\
\hline 1 & Extradition of cash from bank account & 5 & 450 & 37.5 \\
\hline 2 & $\begin{array}{l}\text { Reception of cash from individuals and legal } \\
\text { entities creditied to a bank accounts }\end{array}$ & 5 & 450 & 37.5 \\
\hline 3 & $\begin{array}{l}\text { Reception and extradition of cash for } \\
\text { transactions of it without opening a bank } \\
\text { account }\end{array}$ & 8 & 270 & 36 \\
\hline 4 & Operations with foreign exchange cash & 12 & 112 & 14.9 \\
\hline 5 & $\begin{array}{l}\text { Reception arrangements of establishment of } \\
\text { purchcourse exchange rate of foreign exchange } \\
\text { cash. audit of comformity and presentation of } \\
\text { stand }\end{array}$ & 4 & 22 & 1.5 \\
\hline 6 & $\begin{array}{l}\text { Recalculation of cash that was delivered by } \\
\text { collectors. testing of its authenticity and } \\
\text { creation attented documentation }\end{array}$ & 25 & 40 & 16.6 \\
\hline 7 & $\begin{array}{l}\text { Exchange of banknotes and coins of Bank of } \\
\text { Russia that have injury and defects for the } \\
\text { solvent banknotes and coints }\end{array}$ & 5 & 18 & 1.5 \\
\hline 8 & The alarm system items functionality check & 1 & 22 & 0.4 \\
\hline 9 & $\begin{array}{l}\text { Creation massages about banknotes that has } \\
\text { forgery sings }\end{array}$ & 7 & 7 & 0.8 \\
\hline 10 & $\begin{array}{l}\text { Managing of issure and accept values record } \\
\text { book }\end{array}$ & 8 & 22 & 3 \\
\hline 11 & Daily creation a cash flows certificates & 2 & 22 & 0.7 \\
\hline 12 & Documental fixation of rests in values & 15 & 22 & 5.5 \\
\hline
\end{tabular}




\begin{tabular}{|c|c|c|c|c|}
\hline & depository and checking out in a record book & & & \\
\hline 13 & $\begin{array}{l}\text { Sealing and reception /extradition of values } \\
\text { depository }\end{array}$ & 18 & 22 & 6.6 \\
\hline 14 & Creation cash documents per day & 17 & 22 & 6.2 \\
\hline 15 & $\begin{array}{l}\text { Organisation of cash reception and export in/out } \\
\text { of settlement and cash center and creation } \\
\text { attented documentation }\end{array}$ & 16 & 6 & 1.6 \\
\hline 16 & $\begin{array}{l}\text { Organisation of applications for reinforcement } \\
\text { of repository MR }\end{array}$ & 3 & 22 & 1.1 \\
\hline 17 & $\begin{array}{l}\text { Selling of Bank Russia coins made from } \\
\text { precious metals }\end{array}$ & 6 & 2 & 0.2 \\
\hline 18 & $\begin{array}{l}\text { Reception /extradition of money through } \\
\text { electrical terminals }\end{array}$ & 3 & 60 & 3 \\
\hline 19 & Cheching out of card authenticity & 4 & 100 & 6.6 \\
\hline 20 & $\begin{array}{l}\text { Extradition personalizated cards to banks } \\
\text { clients. its service }\end{array}$ & 11 & 600 & 110 \\
\hline \multicolumn{4}{|c|}{$\begin{array}{ll} & \text { Total } \\
\end{array}$} & 291.2 \\
\hline
\end{tabular}

Based on table 2 it is possible to note that monthly volume of work of the cashier and the senior cashier of JSC «Rosselkhozbank» is 291,2 hours. Because of the small size of given organisation but the volume work is large the employees are completely interchangeable executing similar functions.

The Determination of the planned volume of work a senior account Manager JSC «Rosselkhozbank» is presented in table 3.

Table 3. The Determination of the planned volume of work a senior account Manager JSC «Rosselkhozbank».

\begin{tabular}{|c|l|c|c|c|}
\hline № & \multicolumn{1}{|c|}{ Performed tasks/operations } & $\begin{array}{c}\text { The rate of } \\
\text { time for the } \\
\text { evaluation } \\
\text { of the } \\
\text { employee, } \\
\text { min }\end{array}$ & $\begin{array}{c}\text { Number } \\
\text { of works/ } \\
\text { operations } \\
\text { per month }\end{array}$ & $\begin{array}{c}\text { Momthly } \\
\text { labour } \\
\text { input, h }\end{array}$ \\
\hline 1 & $\begin{array}{l}\text { Learning normative documents of Head Bank } \\
\text { CB RF and other economical and social literature }\end{array}$ & 30 & 4 & 2 \\
\hline 2 & $\begin{array}{l}\text { Creation of an accountability and delivering it to } \\
\text { the branch }\end{array}$ & 240 & 1 & 4 \\
\hline 3 & Creation of credit reports about assigned clients & 7 & 120 & 14 \\
\hline 4 & Organization and transfer of cases to archive & 24 & 130 & 52 \\
\hline 5 & $\begin{array}{l}\text { Consultation and selling of credit products and } \\
\text { cross-products, including programs of collective } \\
\text { insurance to individuals }\end{array}$ & 6 & 130 & 13 \\
\hline 6 & Organization of credit deals in ABS «BISQUIT» & 5 & 120 & 10 \\
\hline 7 & $\begin{array}{l}\text { Making an visual assessment of a client and } \\
\text { filling an questionnaire }\end{array}$ & 2 & 130 & 4.3 \\
\hline 8 & $\begin{array}{l}\text { Asking an written clients agreement for the using } \\
\text { of personal data and making a photo }\end{array}$ & 3 & 130 & 6.5 \\
\hline 9 & $\begin{array}{l}\text { Checking out of client's documents authenticity } \\
\text { in providing retail credit products }\end{array}$ & 3 & 120 & 6 \\
\hline 10 & $\begin{array}{l}\text { Scan of documents that have been taken from a } \\
\text { client and placement them in the scan system }\end{array}$ & 5 & 130 & 11 \\
\hline 11 & $\begin{array}{l}\text { First enter parameters of a credit deal and } \\
\text { supporting contracts in «Credit and Deposits» } \\
\text { IBS «BISQUIT» inputting additional details }\end{array}$ & 6 & 120 & 12 \\
\hline
\end{tabular}




\begin{tabular}{|c|l|c|c|c|}
\hline & $\begin{array}{l}\text { parameters of a credit deal and supporting } \\
\text { contracts }\end{array}$ & 4 & 120 & 8 \\
\hline 12 & $\begin{array}{l}\text { Creation and printing Agreements from IBS } \\
\text { «BISQUIT» }\end{array}$ & 6 & 120 & 12 \\
\hline 13 & $\begin{array}{l}\text { Oganisation and singing contracts, additional } \\
\text { agreements }\end{array}$ & 2 & 32 & 1 \\
\hline 14 & $\begin{array}{l}\text { Inputing adjustments into IBS «BISQUIT» when } \\
\text { parameters are not incompatible in credit deal }\end{array}$ & 4 & 120 & 8 \\
\hline 15 & $\begin{array}{l}\text { Sending scan copies cover letters to responsible } \\
\text { worker DRB }\end{array}$ & & 163.8 \\
\hline \multicolumn{2}{|c|}{ Total } \\
\hline
\end{tabular}

Based on table 3 it is possible to note that monthly volume of work of the senior account Manager of organization is 163,8 hours.

The Determination of the planned complexity of the work of the leading operator TO JSC «Rosselkhozbank» is presented in table 4.

Table 4. The Determination of the planned complexity of the work of the leading operator TO JSC «Rosselkhozbank».

\begin{tabular}{|c|c|c|c|c|}
\hline № & Performed tasks/operations & $\begin{array}{c}\text { The rate of } \\
\text { time for the } \\
\text { evaluation of } \\
\text { the } \\
\text { employee, } \\
\text { min }\end{array}$ & $\begin{array}{l}\text { Number } \\
\text { of works/ } \\
\text { operations } \\
\text { per month }\end{array}$ & $\begin{array}{l}\text { Momthly } \\
\text { labour } \\
\text { input, } h\end{array}$ \\
\hline 1 & Opening and closing of banks accounts & 8 & 100 & 13.3 \\
\hline 2 & $\begin{array}{l}\text { Validation clients' documents during opening a } \\
\text { bank account, replacing a card, a client updates } \\
\text { a package of documents / several documents, } \\
\text { etc. }\end{array}$ & 2 & 60 & 2 \\
\hline 3 & $\begin{array}{l}\text { Reception of payment documents for the } \\
\text { transfer of funds from customer accounts }\end{array}$ & 6 & 350 & 35 \\
\hline 4 & $\begin{array}{l}\text { Signing of certificates issued to customers on } \\
\text { their requests about the state of the settlement } \\
\text { account }\end{array}$ & 4 & 100 & 6.6 \\
\hline 5 & $\begin{array}{l}\text { Creation of a certificate of seized documents on } \\
\text { DO and its transfer by e-mail to the account and } \\
\text { report department (daily, no later than 11-00 the } \\
\text { next business day) }\end{array}$ & 3 & 22 & 1 \\
\hline 6 & $\begin{array}{l}\text { Clarification to depositors of issues related to } \\
\text { the operation of the deposit insurance system }\end{array}$ & 4 & 65 & 4.3 \\
\hline 7 & $\begin{array}{l}\text { Request and receive the necessary information } \\
\text { from individuals and legal entities }\end{array}$ & 7 & 70 & 8.2 \\
\hline 8 & $\begin{array}{l}\text { Familiarization of customers with card products, } \\
\text { conditions, tariff plans, rules for card } \\
\text { transactions, card additional services }\end{array}$ & 3 & 150 & 7.5 \\
\hline 9 & $\begin{array}{l}\text { Reception of documents and execution of the } \\
\text { procedure for interaction with the ACC for the } \\
\text { issue and service of payment cards }\end{array}$ & 18 & 150 & 45 \\
\hline 10 & $\begin{array}{l}\text { Creation and supporting legal cases of card } \\
\text { owners }\end{array}$ & 8 & 50 & 6.6 \\
\hline 11 & Opening, supporting and closing card accounts & 7 & 50 & 5.8 \\
\hline 12 & $\begin{array}{l}\text { Documents reception and validation, disclosure } \\
\text { in the accounts of private operations in } \\
\text { transactions without account opening. }\end{array}$ & 10 & 80 & 13.3 \\
\hline 13 & Scan the received documents from the client & 5 & 120 & 10 \\
\hline
\end{tabular}




\begin{tabular}{|c|c|c|c|c|}
\hline & and place them in the scan system & & & \\
\hline 14 & $\begin{array}{l}\text { Documental organization of operations with } \\
\text { depersonalized metal accounts of individuals }\end{array}$ & 7 & 8 & 1 \\
\hline 15 & Serving Customer Service Pack Owners & 13 & 40 & 8.6 \\
\hline 16 & $\begin{array}{l}\text { Selling Premium Service Packages to Existing } \\
\text { and Potential Customers }\end{array}$ & 17 & 11 & 3.1 \\
\hline 17 & $\begin{array}{l}\text { Client identification and updating of } \\
\text { information received as a result of identification } \\
\text { of the client, his representative, beneficiary in } \\
\text { process changing specified information, as well } \\
\text { as in the process of studying the client and } \\
\text { analyzing his activities }\end{array}$ & 10 & 55 & 9 \\
\hline 18 & $\begin{array}{l}\text { Execution as the operator performing the list of } \\
\text { services specified in the order of money } \\
\text { transfers by order of individuals without } \\
\text { opening bank accounts using money transfer } \\
\text { systems based on MoneyTrans and Western } \\
\text { Union software products }\end{array}$ & 13 & 15 & 3.3 \\
\hline 19 & $\begin{array}{l}\text { Scan the received documents from the client } \\
\text { and place them in the scan system }\end{array}$ & 4 & 50 & 3.3 \\
\hline \multicolumn{4}{|c|}{ Total } & 186.9 \\
\hline
\end{tabular}

Based on table 4 it is possible to note that monthly volume of work of the senior account Manager of organization is 163,8 hours.

The Determination of the planned complexity of the work of senior Manager-operator TO JSC «Rosselkhozbank» is presented in table 5.

Table 5. The Determination of the planned complexity of the work of senior Manager-operator TO JSC «Rosselkhozbank».

\begin{tabular}{|c|l|c|c|c|}
\hline No & \multicolumn{1}{|c|}{ Performed tasks/operations } & $\begin{array}{c}\text { The rate of } \\
\text { time for the } \\
\text { evaluation of } \\
\text { the employee, } \\
\text { min }\end{array}$ & $\begin{array}{c}\text { Number } \\
\text { of works/ } \\
\text { operations } \\
\text { per } \\
\text { month }\end{array}$ & $\begin{array}{c}\text { Momthly } \\
\text { labour } \\
\text { input, h }\end{array}$ \\
\hline 1 & Opening and closing banks accounts & 8 & 150 & 20 \\
\hline 2 & $\begin{array}{l}\text { Validation clients documents during opening a } \\
\text { bank account, when replacing a card, when a } \\
\text { client updates a package of documents, etc. }\end{array}$ & 2 & 100 & 3.3 \\
\hline 3 & $\begin{array}{l}\text { Reception and validation documents of a client } \\
\text { which needed for opening current accounts }\end{array}$ & 3 & 150 & 7.5 \\
\hline 4 & $\begin{array}{l}\text { Reception of payment documents for the } \\
\text { transfer of funds from customer accounts }\end{array}$ & 6 & 550 & 55 \\
\hline 5 & $\begin{array}{l}\text { Reception and validation of cash documents for } \\
\text { reception and issuing cash }\end{array}$ & 3 & 400 & 20 \\
\hline 6 & $\begin{array}{l}\text { Organization a certificates to customers on their } \\
\text { requests about the state of the current account }\end{array}$ & 4 & 100 & 6.6 \\
\hline 7 & $\begin{array}{l}\text { Caneration of monthly summary personal } \\
\text { accounts }\end{array}$ & 180 & 1 & 3 \\
\hline 8 & $\begin{array}{l}\text { Creation of ganaral joining of accounting } \\
\text { documents of the day (daily) }\end{array}$ & 20 & 22 & 7.3 \\
\hline 9 & $\begin{array}{l}\text { Scan the received documents from the client and } \\
\text { place them in the scan system }\end{array}$ & 5 & 120 & 10 \\
\hline 10 & $\begin{array}{l}\text { Clarification to depositors of questions related } \\
\text { to the operation of the deposit insurance system }\end{array}$ & 4 & 150 & 10 \\
\hline 11 & Execution of documents for deposit operations & 7 & 70 & 8.2 \\
\hline
\end{tabular}




\begin{tabular}{|c|c|c|c|c|}
\hline & $\begin{array}{l}\text { for further work with them and the subsequent } \\
\text { transfer to the archive }\end{array}$ & & & \\
\hline 12 & $\begin{array}{l}\text { Opening and closing of an account to clients for } \\
\text { accounting credit, deposit operations, operations } \\
\text { with securities }\end{array}$ & 12 & 110 & 22 \\
\hline 13 & $\begin{array}{l}\text { Off-balance sheet accounting of strict reporting } \\
\text { forms }\end{array}$ & 9 & 22 & 3.3 \\
\hline 14 & $\begin{array}{l}\text { Documents reception and validation, disclosure } \\
\text { in the accounts of private operations in } \\
\text { transactions without account opening }\end{array}$ & 10 & 80 & 13.3 \\
\hline 15 & $\begin{array}{l}\text { Entering all necessary additional details to } \\
\text { deposit accounts }\end{array}$ & 5 & 65 & 5.4 \\
\hline 16 & $\begin{array}{l}\text { Execution of functions as the operator } \\
\text { performing the list of services specified in the } \\
\text { order of money transfers by order of individuals } \\
\text { without opening bank accounts using money } \\
\text { transfer systems based on MoneyTrans and } \\
\text { Western Union software products }\end{array}$ & 13 & 15 & 3.3 \\
\hline 17 & $\begin{array}{l}\text { Documental organization of operations with } \\
\text { depersonalized metal accounts of individuals }\end{array}$ & 7 & 8 & 1 \\
\hline 18 & $\begin{array}{l}\text { Scan of documents that have been taken from a } \\
\text { client and placement them in the scan system }\end{array}$ & 4 & 150 & 10 \\
\hline 19 & Serving Customer Service Pack Owners & 13 & 20 & 4.3 \\
\hline \multicolumn{4}{|c|}{ Total } & 216.8 \\
\hline
\end{tabular}

Monthly volume of work of the senior Manager-operator of organization is 216,8 hours.

\section{Discussion}

The completeness of using of personnel by TO JSC «Rosselkhozbank» can be estimated by the number of worked days and hours by the employees per month, also by the degree of using of the working time fund. Such an analysis for each employee of TO JSC «Rosselkhozbank» is presented in table 6.

Table 6. The Use of the working time Fund of employees TO JSC «Rosselkhozbank».

\begin{tabular}{|c|c|c|c|}
\hline \multirow{2}{*}{ Employees } & \multicolumn{2}{|c|}{ Average monthly Fund of employees, $h$} & \multirow{2}{*}{$\begin{array}{l}\text { change } \\
\text { surplus }\end{array}$} \\
\hline & plan & fact & \\
\hline Chief Cashier & \multirow{5}{*}{147.6} & 145.6 & - \\
\hline Cashier & & 145.6 & - \\
\hline Supervising Account Manager & & 163.8 & 16.2 \\
\hline Leader Checkout Clerk & & 186.9 & 39.3 \\
\hline Chief Checkout Clerk & & 216.8 & 69.2 \\
\hline All employees & 738 & 858.7 & 124.7 \\
\hline
\end{tabular}

Based on the data in table 6 , we can conclude that only the cashier and the senior cashier of the additional office work out practically the prescribed amount of working time per month. The complexity of the work of the rest of the staff is that they are forced to process a month from 16 hours for a senior client manager to 70 hours for a senior operating manager.

Calculation of the needs of TO JSC «Rosselkhozbank» in employees will carry out in table 7. 
Table 7. The Calculation of the planned number of employees TO JSC «Rosselkhozbank» on the complexity of their work.

\begin{tabular}{|c|c|c|c|c|c|c|c|}
\hline \multirow{2}{*}{ Employees } & \multirow{2}{*}{ EWT. h } & \multirow{2}{*}{ SLI. h } & \multirow{2}{*}{ IRS } & \multirow{2}{*}{ Calculation } & \multicolumn{2}{|c|}{ Number } & \multirow{2}{*}{$\begin{array}{c}\text { Change } \\
\text { suplus }\end{array}$} \\
\hline & & & & & plan & fact & \\
\hline Chief Cashier & \multirow{5}{*}{147.6} & 145.6 & \multirow{5}{*}{1} & $145.6 / 147.6$ & 1 & 1 & - \\
\hline Cashier & & 145.6 & & $145.6 / 147.6$ & 1 & 1 & $\square$ \\
\hline $\begin{array}{c}\text { Supervising } \\
\text { Account } \\
\text { Manager }\end{array}$ & & 163.8 & & $163.8 / 147.6$ & 1.1 & 1 & $\square$ \\
\hline $\begin{array}{c}\text { Leader } \\
\text { Checkout Clerk }\end{array}$ & & 186.9 & & $186.9 / 147.6$ & 1.3 & 1 & $\square$ \\
\hline $\begin{array}{l}\text { Chief Checkout } \\
\text { Clerk }\end{array}$ & & 216.8 & & $216.8 / 147.6$ & 1.5 & 1 & $\square$ \\
\hline
\end{tabular}

\section{Conclusions}

Based on the obtained data, reflected in table 7, we can conclude. The planned and actual number of employees of cashier and senior cashier positions is the same. This means that there is no additional need for these employees.

Supervising Account Manager over fulfills the norms on $10 \%$, but this is quite acceptable and does not mean the involvement of another employee.

As for Leader Checkout Clerk and Chief Checkout Clerk, their over fulfillment of norms is much bigger and varies from 40 to 70 hours per month. This indicates about a high level labour intensity of the employees of the operational department, and as a result, is characterized by constant delays in the workplace of these employees after the working day.

So, based on cattied out calculations, we can note the lack of specialists in the credit and operational departments. But if the actual number of employees implies an over fulfillment of standards by the Supervising Account Manager on $10 \%$, which is quite acceptable and realistic, then for the employees of the operations department this over fulfillment is already from 25 to $50 \%$. Such over fulfillment of norms can also take place, but testifies about a extremely high intensity of labour of employees of the operational department and the lack of their number.

A great importance for the implementation of the energy conservation program and to achieve its effectiveness has the involvement of all participants of the process, who really can have a positive impact to the achievement of the main goals and the implementation of tasks.

So, a synergistic effect will be achieved from a balanced distribution of functions of performers, cost reduction, identification and elimination of unproductive expenses, image attractiveness of the company in the eyes of business partners, the public and government; ensuring managerial transparency and increasing the manageability of the company.

\section{References}

1. O. Klopova, L. Komyshova, M. Simonova, Problems and Perspectives in Management 16(1), 214-223 (2018)

2. O.U. Minchekova, Personnel Management: budgeting system: training manual (KNORUS, Moscow, 2018)

3. S.I. Sergeeva, L.N. Komyshova, N.A. Nagibina, E3S Web Conf. High-Rise Construction 2017 (HRC 2017), Construction Technology and Management 33 (2018)

4. V.P. Pashuto, Organization, regulation and remuneration at the enterprise: training 
manual (KNORUS, Moscow, 2017)

5. L.N. Komyshova, S.I. Sergeeva, Economics and entrepreneurship 10-1(87), 97-100 (2017)

6. I. Lukmanova, R. Golov. Modern energy efficient technologies of high rise $\begin{array}{llllll}\text { construction. } & \text { E3S Web of Conferences 33, } 02047 \quad \text { (2018) }\end{array}$ https://doi.org/10.1051/e3sconf/20183302047

7. S.A. Tinkov, E.V. Tinkova Indicator to Assess the Level of Development of Productive Capacity and Quality of Life. Smart Innovation, Systems and Technologies, 139 (2019) DOI: 10.1007/978-3-030-18553-4_69 